\title{
Aanpak van langdurige klachten na COVID-19
}

Fleur Otto, Hanneke Stam, Jacoba Greving

De nieuwe NHG-Standaard Langdurige klachten na COVID-19 beschrijft de diagnostiek en het beleid voor volwassen patiënten die langer dan 4 weken klachten houden na infectie met SARS-CoV-2. Deze standaard is onderdeel van een integrale, evidencebased multidisciplinaire richtlijn, die is ontwikkeld op initiatief van het Nederlands Huisartsen Genootschap, de Federatie Medisch Specialisten en de Long Alliantie Nederland.

Uit de nu beschikbare gegevens (van ongevaccineerde patiënten) blijkt dat ongeveer de helft van alle patiënten die COVID-19 doorgemaakt hebben, na 3 maanden nog niet geheel klachtenvrij is. Precieze frequenties variëren enorm per onderzoek en zijn grotendeels afhankelijk van de onderzochte populatie en het tijdstip na infectie. Hoewel er momenteel geen gegevens beschikbaar zijn over langdurige klachten na COVID-19 bij gevaccineerden, mogen we aannemen dat iedereen die COVID-19 heeft doorgemaakt langdurige klachten kan ontwikkelen. De belangrijkste klachten zijn vermoeidheid, verminderde inspanningsintolerantie, spierzwakte, dyspneu, cognitieve klachten en reuk- of smaakstoornissen. Ook hebben veel patiënten last van angst en slaapproblemen.

In de eerste 3 maanden na de acute infectie zien we de grootste daling van het aantal klachten bij patiënten. Daarna verloopt de afname van de klachten (zowel in aantal als intensiteit) minder snel. Patiënten met een ernstiger beloop van de acute infectie of meer klachten ten tijde van de acute infectie lijken een hoger risico te lopen op langdurige klachten.

\section{DIAGNOSTIEK}

Patiënten komen met uiteenlopende klachten op het spreekuur en vaak hebben ze meerdere klachten tegelijkertijd. Afhankelijk van het moment waarop de patiënt $\mathrm{u}$ raadpleegt, de aard van de (ingangs)klachten en hulpvraag neemt u een meer of minder uitgebreide anamnese af. Kijk daarbij ook naar de manier waarop de patiënt met de klachten omgaat en het effect op het dagelijks functioneren. Omdat spiermassa en conditie bij bedlegerigheid snel afnemen, is het belangrijk om alert te zijn op spiermassaverlies, zeker bij klachten van spierzwakte of balansproblemen [kader].

Voer lichamelijk onderzoek uit op grond van het individuele klachtenpatroon en de differentiële diagnose.

Oriënterend laboratoriumonderzoek, een X-thorax of inspanningstests lijken niet bij te dragen aan het aantonen, dan wel uitsluiten van aan COVID-19 gerelateerde pathologie. Verricht dan ook alleen aanvullend onderzoek wanneer $u$ vermoedt dat de klachten een andere oorzaak hebben.

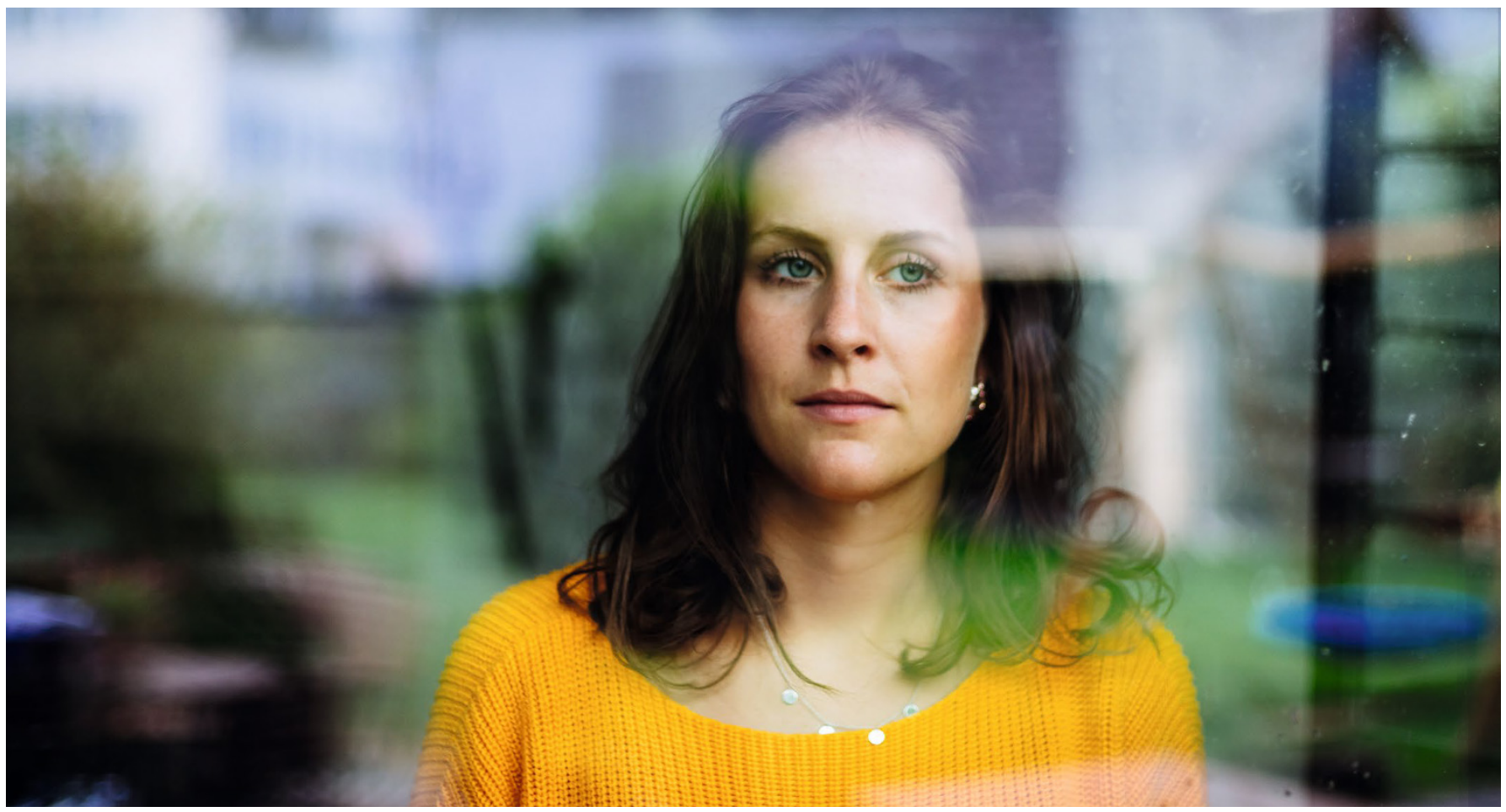




\section{RISICO OP SPIERMASSAVERLIES}

Wees alert op mogelijk spiermassaverlies/spierkrachtverlies bij:

- onbedoeld gewichtsverlies sinds COVID-19 [of afgelopen 6 maanden $\geq 4 \mathrm{~kg}$ of $\geq 5 \%$ ]

- spierzwakte, onvoldoende balans [bijvoorbeeld bij het opstaan]

- verminderde voedingsinname door gebrek aan eetlust, reuk- en/of smaakverlies of andere aan COVID-19 gerelateerde maagdarmproblemen

\section{BELEID}

Bij de aanpak van langdurige klachten na COVID-19 kunt u onderscheid maken tussen enkelvoudige klachten en meerdere, met elkaar samenhangende klachten. In beide gevallen zullen het inventariseren en vervolgen van de klachten en het begeleiden van de patiënt vaak meer consulten beslaan. Besteed hierbij aandacht aan de biologische, psychologische en sociale aspecten. Bepaal in samenspraak met de patiënt of behandeling gewenst is of dat in eerste instantie kan worden afgewacht. Er is geen bewijs dat medicamenteuze behandeling het herstel van langdurige klachten bevordert.

De standaard geeft voor de meest voorkomende langdurige klachten per klacht adviezen over voorlichting en verwijzing. De eerste 6 weken na COVID-19 ligt de nadruk op leefstijladviezen. Na 6 weken kunt $u$ in overleg met de patiënt besluiten om een paramedicus bij de behandeling te betrekken. Bij vermoeidheidsklachten en energiemanagement kan de ergotherapeut een belangrijke rol spelen. Overweeg verwijzing naar een medisch specialist wanneer de patiënt ondanks eerstelijnsbehandeling onvoldoende herstelt.

Bij meerdere klachten zult $u$ de patiënt vaak naar verschil- lende paramedici verwijzen. Hier ligt een uitdaging voor alle betrokken zorgverleners: op basis van de gestelde doelen dienen zij de interventies op elkaar af te stemmen en zo nodig (gezamenlijk) te evalueren. Bepaal in onderling overleg welke zorgverlener deze multidisciplinaire behandeling coördineert. Overweeg in de volgende gevallen verwijzing naar de tweede lijn voor een multidisciplinair overleg:

1. bij onvoldoende herstel van matig ernstige samenhangende klachten na $\geq 6$ maanden behandeling in de eerste lijn;

2. bij grote complexiteit van klachten;

3. bij diagnostische twijfel over de vraag of de combinatie van de klachten en het beloop past bij herstel na COVID-19.

Blijf bij langdurige (of verergerende) klachten na COVID-19 alert op andere of bijkomende oorzaken, zoals hartfalen, astma/COPD, angina pectoris, longembolie of een (nieuwe) respiratoire infectie. Zie de betreffende standaarden voor diagnostiek en beleid.

Greving J, Otto F, Stam H, namens de werkgroepen NHG-Standaard en multidisciplinaire richtlijn. Aanpak van langdurige klachten na COVID-19. Huisarts Wet 2022;65[4]: 48-9]. D0I:10.1007/s12445022-1417-7.

Nederlands Huisartsen Genootschap, afdeling Richtlijnontwikkeling, Utrecht: F. Otto, huisarts, wetenschappelijk medewerker,

f.otto@nhg.org; H. Stam, huisarts, wetenschappelijk medewerker;

J. Greving, wetenschappelijk medewerker.

De NHG-werkgroep bestond uit [alfabetische volgorde]: P. Bindels, J.P.

Greving, J. van Hardeveld, E. Janszoon, F. Otto, R. van Schie, H. Stam,

H. in 't Veen, R. Venekamp, C. Wassing-Molema, R. Wennekes.

Mogelijke belangenverstrengeling: niets aangegeven.

Raadpleeg de volledige versie van de NHG-Standaard Langdurige klachten na COVID-19 op richtlijnen.nhg.org. 